\title{
After Humanity: technology, ecology and a blueprint for speculative media
}

\section{Garfield Benjamin}

\begin{abstract}
After Humanity approaches issues of technological futures, environmental collapse and human agency. The eponymous future after the fall of humanity imagines a world built through relations between machines and ecology, in order to critique human priorities and the impact of constant expansion on the environment. This is situated in the context of developing a combined speculative media method, fusing design, fiction and ethics. The work is offered as a proof of concept for the method in developing a specific context using machine learning and human creative practices.
\end{abstract}

Keywords: posthumanism, artificial intelligence, machine learning, speculative design, anthropocene, science fiction, tech ethics

\section{Link to work [https://digitalcultu.re/media/afterhumanity/]}

after humanity, the world is scarred and ruined: what remains in its wake?

land and sea are reclaimed as human excess rots and fades : what else will evolve?

from machines and nature, new ecosystems are born : a posthuman world?

This speculative design project combines machine learning and organic structures to imagine a posthuman world, anticipating new forms of civilisation that may emerge after humanity ends. In doing so, we can spark discussions around technoethics and ecology, and inform hybrid design in the present. We ask, how can we use concepts from humans, animals and machines to generate more sustainable futures for all species?

We imagine a fusion of machine and ecology to wonder what technology and earth would look like after humanity. By posthuman, we take three separate meanings: - a technological singularity created by humanity that fundamentally changes the species and its relation to the world. This acknowledges the persistent role of the utopian dreams of science fiction and the tech industry, while critiquing the power such perspectives hold over the future of society and the planet;

- the development of the world after human extinction, a future defined by animals and/or machines. Here we build on Haraway's (2016) conception of the anthropocene 
as a framework of economics and power structures, contrasted with the chthuluscene in which the earth reigns and humans are reduced to compost;

- a critical posthumanism, following Rosi Braidotti (2013), which deconstructs the frameworks, assumptions and priorities of humanism, technology and posthuman desire. The driving force of this strand is to introduce opportunities to consider human and non-human perspectives of Otherness.

This posthumanism therefore emphasises human responsibility while rejecting human privilege, a fusion of art, philosophy and technology, a call to action for (re)designing the future.

In order to inspire posthuman debates and critically assess the role of humanity in ecology, the designs in this speculative work are co-created between human, machine and the environment. The work starts as a visualisation of the collapse of human society, resulting in a new, scarred landscape in which new societies emerge. To imagine what this new world might look like, we take an oil rig - a human structure signifying the negative ecological impact of an exploitative relationship with the planet. The oil rig is generated using Google DeepMind's bigGAN, a generative adversarial network built from a massive dataset of one thousand categories of objects, and specifically the image generation templates developed by Gene Kogan (2018). This is further manipulated by the machinic creativity by metamorphosing the human artefact of the network's latent space with the potential for environmental creativity - the oil rig is combined with bigGAN images of (non-mammalian) animals, plants, fungi and landscape features in order to generate the seeds of new architectural structures that might coexist more productively with the ecological system. By removing the human from this process, we begin to see what creations might emerge in our wake once our tools are left to the own devices and co-opted by other species. In order to frame the work as a critical posthuman piece, the human artist re-enters to convert the bigGAN image into a $3 d$ blueprint, alongside an emerging fictional thread describing the creative potential of the planet 'after humanity'.

After Humanity is a new work, available online, that forms the blueprint and initial proof of concept for ongoing research into developing a speculative media method combining fiction, design and ethics. From speculative design, we take the production of concrete objects and technologies as a provocation of possible futures. We focus on design as a process of asking questions rather than providing answers (Dunne and Raby 2013). But we also move from design strictly conceived into a more explicit relation with art practice, in order to approach further "speculative dimensions, which are not content to modify but more radically dismantle technology" (Parikka 2015). In After Humanity, this leads to the machine-ecology blueprints for alternative structures. From speculative fiction, we take the world building process of social thought experiments (Le Guin 2018), estranging our perspective historically and cognitively in order to critique the present (Suvin 1979; Jameson 2005). But we also consider individual perspectives of what it is like to live in alternative contexts, revealing inequalities and priorities in how the future might unfold. In After Humanity, we invert the 'outside context problem' (Banks 2008) offered by speculative scenarios through an act of speculative removal. Instead of imagining what it would be like for humans to live in alternative societies or futures, we 
imagine an alternative future without humanity, in which machines and ecology realign their priorities and prejudices to reconstruct the world anew. The fictional snippets attached to each design provide a more explicit world-building approach, along with a consideration of how and why these structures have developed as well as how they fit into broader phylogenetic orders and the relations between different 'species'. Here we move into speculative ethics. Bogost (2012) places a limit on speculative ethics - when considering the ethics of relations between non-human things - as always being the relation of humans to that non-human relation. In After Humanity we embrace and push against that limit, precisely to explore the relation of humanity to its own absence, and thereby reinsert the responsibility of ecological damage even as we consider the relations between machines and ecology. We invoke concrete ethical consideration of relations and futures in order to 'think otherwise' (Gunkel 2007) - to challenge the ethics of exclusion as boundaries of ethics. This is furthered (Gunkel 2018) by inverting the dominant ethical narratives of taking what technologies are emerging or possible. Instead, we place what 'ought' to be before what 'is' (or what might be), applied here within the speculative model to consider the ethics of competing priorities in determining the societal and design choices that underpin new political and ecological structures.

By constructing the method and the work in this way, we are attempting to stretch our "temporal imagination over primordial and post-extinction realities" (Kara 2016, 758). And, even further we combine fiction, design and ethics so that "the notion of speculation becomes tied to a specific non-human temporality as well" (Parikka 2015). We develop the context After Humanity in order to speculate on the implications of relational ethics of technology and ecology in the present climate crisis. The work forms a preliminary test of this framework. This method is being further tested and developed in The Speculative City, a VR project that reimagines Southampton, UK, in speculative contexts building on the setting and techniques of After Humanity.

\section{References}

Banks, lain M. 2008 [1996]. Excession. London: Hachette.

Bogost, Ian (2012) Alien Phenomenology, or What It's Like to Be a Thing. Minneapolis, MN: University of Minnesota Press.

Braidotti, Rosi. 2013. The Posthuman. Cambridge: Polity.

Dunne, Anthony \& Raby, Fiona. 2013. Speculative everything: design, fiction, and social dreaming. Cambridge, MA: MIT press.

Gunkel, David (2007) Thinking otherwise: Ethics, technology and other subjects. Ethics and Information Technology 9(3),165-177.

Gunkel, David (2018) The other question: can and should robots have rights?

Ethics of Information Technology 20, 87-99. 
Garfield Benjamin, After Humanity (prepring, forthcoming in Int. Jour. Creative Media Research) 4

Haraway, Donna. 2016. Staying with the Trouble: Making Kin in the Cthulucene.

Durham, NC: Duke University Press.

Kara, Selmin (2016) Anthropocenema: Cinema in the Age of Mass Extinctions. In Shane Denson and Julia Leyda, Post-Cinema: Theorizing 21st-Century Film. Falmer: REFRAME. 750-784.

Kogan, Gene. 2018. BigGAN Colaboratory. Tensorflow Hub.

https://colab.research.google.com/drive/1rqDwlddy0eunhhV8yrznG4SNiB5XWFلl

Jameson, Fredric. 2005. Archaeologies of the Future: The Desire Called Utopia and Other Science Fiction. London: Verso.

Le Guin, Ursula. 2018 [1969]. The Left Hand of Darkness. London: Orion.

Parikka, Jussi (2015) Mutating media ecologies. continent 4(2), 24-32.

Suvin, Darko. 1979. Metamorphoses of Science Fiction: On the Poetics and History of a Literary Genre. New Haven, CT: Yale University Press. 